\title{
The Psychological Impact of Hemodialysis on Patients with Chronic Renal Failure
}

\author{
Liang-Jen Wang ${ }^{1,2}$ and Chih-Ken Chen ${ }^{1,2}$ \\ ${ }^{1}$ Department of Psychiatry, Chang Gung Memorial Hospital, Keelung, \\ ${ }^{2}$ Chang Gung University School of Medicine, Taoyuan
}

Taiwan

\section{Introduction}

Renal disease is common throughout the world. In the United States alone, almost 100,000 people began renal replacement therapy (RRT) for end-stage renal disease (ESRD) in 2001(Kimmel \& Peterson, 2005); by 2008, this number had increased to 485,000 patients (Collins et al., 2009). More than $90 \%$ of these patients were started on hemodialysis (HD), while only $8.5 \%$ began RRT with peritoneal dialysis (PD)(Kimmel \& Peterson, 2005). In Korea, the number of dialysis centers and machines has continuously increased, and $62.1 \%$ of patients receiving RRT were being treated with HD (Son et al., 2009). An international comparison showed that Taiwan has the greatest incidence and second-greatest prevalence of ESRD (Kuo et al., 2007). Furthermore, renal disease is one of the top 10 causes of death in Taiwan, and roughly 95\% of ESRD patients are on HD (Hsieh et al., 2007).

While HD does not cure renal disease, its use does allow patients with ESRD to survive (Weisbord et al., 2007a). Nevertheless, HD is a lifelong treatment that significantly and sometimes adversely affects patients both physically and mentally (Kimmel, 2001). Common psychological effects include depression, anxiety, fatigue, decreased quality of life (QoL) and increased suicide risk (Chen et al., 2010). The global effects of continual treatment lead to changes in patients' family roles and ability to work, with feelings of loss of control and fear of death. These very real psychological consequences of treatment may affect survival in HD patients (Chilcot et al., 2011; Kimmel \& Peterson, 2005). Therefore, it is imperative to identify and treat these psychological symptoms among HD patients.

\section{Depression}

\subsection{Prevalence and influence of depression}

Depression is one of the most common psychological problems among HD patients. We still lack reliable data that can be used to directly compare the prevalence of depression between HD patients and the general population. However, extant investigations generally agree that the rate of depression is high among HD patients.

In the general population, the lifetime prevalence of major depressive disorder is about $16.2 \%$ (Kessler et al., 2003). However, the rates vary widely across countries, ranging from 


\begin{tabular}{|c|c|c|c|c|}
\hline Study & $\begin{array}{c}\text { Number of } \\
\text { patients }\end{array}$ & $\begin{array}{c}\text { Assessment } \\
\text { tools }\end{array}$ & Prevalence & Additional o \\
\hline $\begin{array}{l}\text { Kurella et al. } \\
(2005)\end{array}$ & 465,563 & $\begin{array}{l}\text { Medical } \\
\text { evidence form } \\
\text { in Medicare } \\
\text { and Medicaid } \\
\text { Services }\end{array}$ & $\begin{array}{l}\text { Withdrew from dialysis: } \\
9.6 \% \\
\text { Died from suicide: } \\
0.005 \%\end{array}$ & $\begin{array}{l}\text { Persons with ESRD } \\
\text { significantly higher } \\
\text { than in the general } \\
\text { Independent predic } \\
\text { suicide: age }>75 \mathrm{yr} \text {, } \\
\text { geographic region, } \\
\text { drug dependence, a } \\
\text { hospitalization with } \\
\text { illness. }\end{array}$ \\
\hline $\begin{array}{l}\text { Taskapan et al. } \\
(2005)\end{array}$ & 40 & $\begin{array}{l}\text { HDRS, HARS, } \\
\text { PRIME-MD, } \\
\text { MMSE, SF-36 }\end{array}$ & $\begin{array}{l}\text { Depression: } 30 \% \\
\text { Anxiety: } 35 \% \\
\text { Somatoform disorder: } \\
32.5 \%\end{array}$ & $\begin{array}{l}\text { All patients' MMSE } \\
\text { No relationship bet } \\
\text { psychiatric disorde } \\
\text { demographic chara } \\
\text { Negative correlatio } \\
\text { weight gain and Qo } \\
\text { dialysis. }\end{array}$ \\
\hline $\begin{array}{l}\text { Drayer et al. } \\
(2006)\end{array}$ & 62 & $\begin{array}{l}\text { PRIME-MD, } \\
\text { KDQOL-SF }\end{array}$ & Depression: 28\% & $\begin{array}{l}\text { Depressed patients } \\
\text { and had lower healt } \\
\text { QoL. Depression pr } \\
\text { mortality in a mean } \\
29 \text { months. } \\
\end{array}$ \\
\hline $\begin{array}{l}\text { Kalender et al. } \\
(2007 a)\end{array}$ & $\begin{array}{l}\text { HD: } 68 \\
\text { PD: } 47\end{array}$ & BDI, SF-36 & $\begin{array}{l}\text { Depression in HD: } \\
33.8 \% \\
\text { Depression in PD: } 12.8 \%\end{array}$ & $\begin{array}{l}\text { Significant negative } \\
\text { between QoL and d } \\
\text { Significant positive } \\
\text { between the QoL ar } \\
\text { value and serum all } \\
\text { Inverse correlation } \\
\text { QoL and the serum } \\
\text { the HD patients. }\end{array}$ \\
\hline
\end{tabular}




\begin{tabular}{|c|c|c|c|c|}
\hline Study & $\begin{array}{c}\text { Number of } \\
\text { patients }\end{array}$ & $\begin{array}{l}\text { Assessment } \\
\text { tools }\end{array}$ & Prevalence & Adc \\
\hline Cukor et al. (2008) & 70 & $\begin{array}{l}\text { SCID, HADS, } \\
\text { KDQOL-SF }\end{array}$ & $\begin{array}{l}\text { Depression: } 29 \% \\
\text { Anxiety: } 45.7 \%\end{array}$ & $\begin{array}{l}\text { Patients with per } \\
\text { marked decrease } \\
\text { health status, con } \\
\text { and intermittentl }\end{array}$ \\
\hline Hedayati et al. (2008) & 98 & $\begin{array}{l}\text { SCID, BDI, CDI, } \\
\text { CESD }\end{array}$ & $\begin{array}{l}\text { Depression: } 26.7 \% \\
\text { Major depression: } 17.3 \%\end{array}$ & $\begin{array}{l}\text { There were no dif } \\
\text { hospitalization fo } \\
\text { depressed. Patien } \\
\text { increased risk of } \\
\text { year. }\end{array}$ \\
\hline $\begin{array}{l}\text { Ibrahim \& Salamony } \\
\text { (2008) }\end{array}$ & 60 & $\begin{array}{l}\text { BDI, SF-36, DSI, } \\
\text { MIS }\end{array}$ & Depression: $33.3 \%$ & $\begin{array}{l}\text { Depression was a } \\
\text { marital status. DS } \\
\text { correlations with } \\
\text { correlations with }\end{array}$ \\
\hline Hsu et al. (2009) & 51 & HADS & Depression: 35\% & $\begin{array}{l}\text { Depression was } \\
\text { used polysulfone } \\
\text { who used cellulo } \\
\text { Depression was a } \\
\text { albumin, and nur }\end{array}$ \\
\hline Kao et al. (2009) & 861 & SF-36, BDI & $\begin{array}{l}\text { Depression: } 60.5 \% \\
\text { Insomnia: } 31.0 \% \\
\text { Fatigue: } 30.6 \%\end{array}$ & $\begin{array}{l}\text { Depression scores } \\
\text { with QoL. Higher } \\
\text { increased social a } \\
\text { better health-rela }\end{array}$ \\
\hline Son et al. (2009) & 146 & $\begin{array}{l}\text { BDI, PHQ-9, } \\
\text { KDQOL }\end{array}$ & Depression: $25.3 \%$ & $\begin{array}{l}\text { There were more } \\
\text { reported in depre } \\
\text { depressed ones. }\end{array}$ \\
\hline Bossola et al. (2010) & 80 & $\begin{array}{l}\text { BDI, HARS, SF- } \\
\text { 36, SCL-90-R } \\
\text {,CCI; MMSE }\end{array}$ & $\begin{array}{l}\text { Depression: } 52.5 \% \\
\text { Mild anxiety: } 47.5 \% \\
\text { Moderate to severe } \\
\text { anxiety: } 48.7 \%\end{array}$ & $\begin{array}{l}\text { BDI score correla } \\
\text { CCI, SF-36 Vitalit } \\
\text { albumin, plasma } \\
6 \text { levels. }\end{array}$ \\
\hline
\end{tabular}




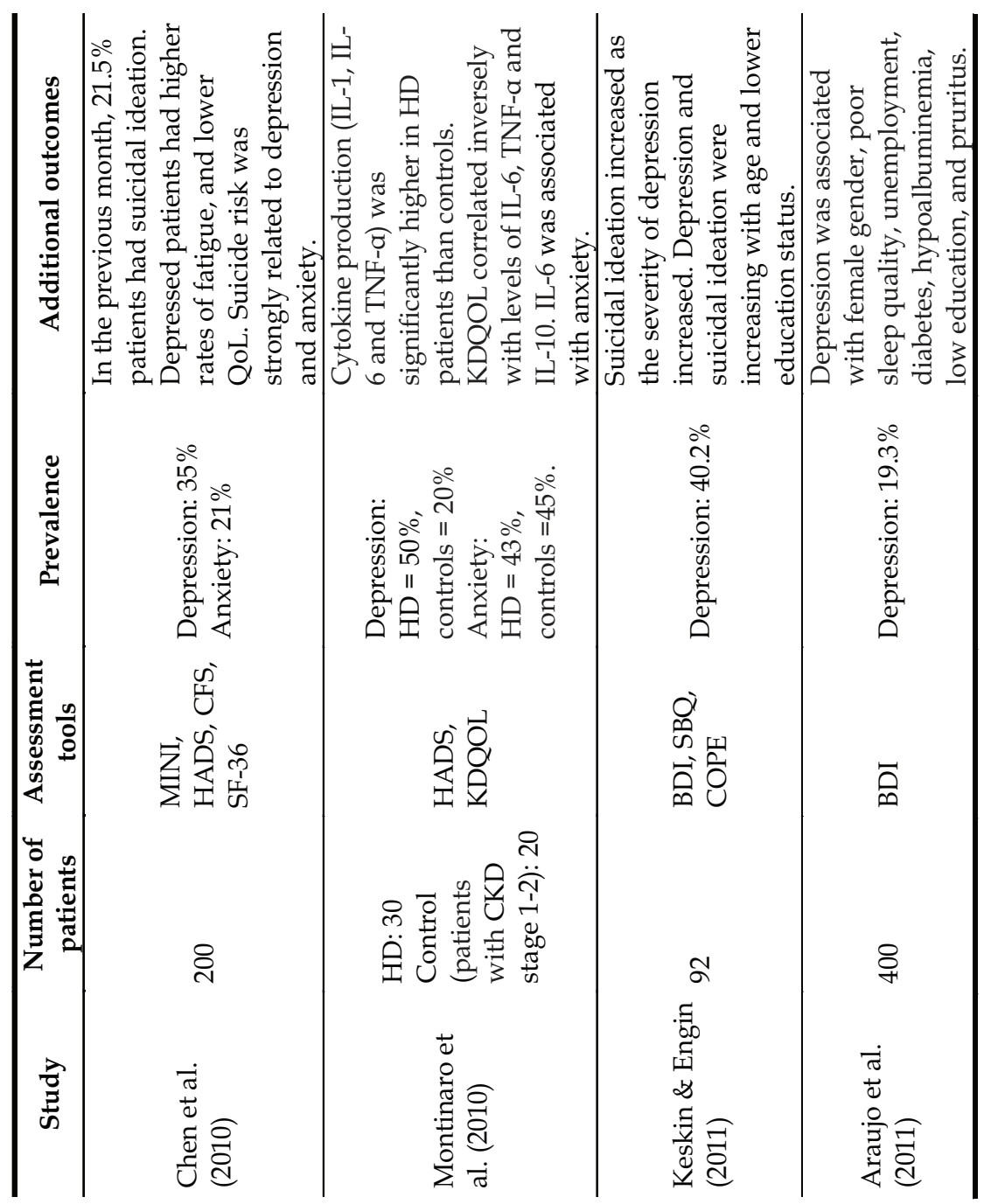

KEY: BDI: Beck Depression Inventory; CCI: Charlson Comorbidity Index; CESD: Center of Epidemiological Studies Depression Scale; CFS: Chalder Fatigue Scale; CKD: chronic kidney disease; COPE: Coping Orientation to Problems Experienced Inventory; CRP: C-reactive protein; DSI: Dialysis Symptom Index; HADS: Hospital Anxiety and Depression Rating Scale; ESRD: end-stage renal disease; HARS: Hamilton Anxiety Rating Scale; HD: hemodialysis; HDRS: Hamilton Depression Rating Scale; IL: interleukin; KDQoL: Kidney Disease Quality of Life; KDQoL-SF: Kidney Disease and Quality of Life Short Form; MINI: Mini International Neuropsychiatric Interview; MIS: Malnutrition-Inflammation Score; MMSE: Mini Mental State Examination; PD: peritoneal dialysis; PHQ-9: Patient Health Questionnaire; PRIME-MD: Primary Care Evaluation of Mental Disorders; SBQ: Suicide Behaviours Questionnaire; SCID: Structured Clinical Interview for DSM; SCL-90-R: Hopkins Symptom Checklist 90 Revised; SF-36: The Short-form Health-related Quality of Life; TNF: tumor necrosis factor Table 1. Psychological impacts in hemodialysis patients demonstrated in recent studies 
The variation in prevalence rates of depression might be accounted for by differences in sample sizes and assessment tools (Watnick et al., 2005). Despite such discrepancies, depression is unquestionably one of the most important mental illnesses among HD patients. Strong correlations have been noted between depression and longitudinal outcome among HD patients, including poor treatment adherence and higher mortality rates (Drayer et al., 2006; Kimmel et al., 1993). In addition, depression in HD patients is associated with higher rates of hospital admission, and a greater likelihood of emergency department visits (Abbas Tavallaii et al., 2009; Hedayati et al., 2008).

\subsection{Biological factors underlying depression}

The etiology of dialysis-related depression is multifactorial, and is related to biological, psychological, and social mechanisms (Chilcot et al., 2008). Some of the biological mechanisms include increased cytokine levels, possible genetic predisposition, and neurotransmitters affected by uremia (Kimmel, 2001; Smogorzewski et al., 1995).

For decades it's been known that immunologic factors have potent influences on neurotransmitter metabolism and neuroendocrine function (Irwin \& Miller, 2007; Wichers \& Maes, 2002). A growing number of studies have investigated the relationships between cytokines and depression (Howren et al., 2009; Loftis et al., 2010; Sonikian et al., 2010). During hemodialysis, the blood-dialyzer interaction has the potential to activate mononuclear and dendritic cells, leading to production of inflammatory cytokines (Agrawal et al., 2010; Pertosa et al., 2000). Several researchers support the supposition that proinflammatory cytokines are involved with depression in renal patients. In particular, there is evidence that depression is associated with interleukin (IL)-1, IL-6, tumor necrosis factoralpha (TNF-a), and C-reactive protein (CRP) in both the general and ESRD populations (Gill et al., 2010; Simic Ogrizovic et al., 2009; Sonikian et al., 2010). These pro-inflammatory cytokines also appear to be associated with survival rate in HD patients (Kimmel et al., 1998). The underlying biological mechanisms have been proposed as a defect in serotonergic function and hypercortisolemia associated with stimulation of the hypothalamic-pituitaryadrenal (HPA) axis (Capuron \& Miller, 2011; Leonard, 2010), thus leading to depression and affecting mortality.

Malnutrition, which is commonly observed in dialysis patients, is related to chronic inflammation (Pertosa et al., 2000). It has also been reported that malnutrition is associated with emotional symptoms among HD patients (Bossola et al., 2009; Czira et al., 2011; Huang \& Lee, 2007; Ibrahim \& El Salamony, 2008; Koo et al., 2003). These authors also determined that patients with depression had lower-than-normal body mass indices (BMI) (Chen et al., 2010).

There is evidence of an association between malnutrition, inflammation, and atherosclerosis (MIA) in ESRD patients, and some researchers have suggested that depression might be involved in the MIA syndrome (Simic Ogrizovic et al., 2009). Others have demonstrated frequent and close relationships between serum albumin levels and depression (Huang \& Lee, 2007; Hung et al., 2011; Koo et al., 2003). However, a correlation between hemoglobin, ferritin, and emotional symptoms is less clear-cut (Bossola et al., 2009; Czira et al., 2011; Huang \& Lee, 2007). Hopefully the causal relationships in the complexity of psychoneuroimmune mechanisms will be further elucidated in future studies. 
Racial effects on depression and anxiety have been studied in HD patients, once again with conflicting results (Feroze et al., 2010). Higher prevalence rates of major depressive disorders have been noted among Caucasians than among African-Americans or MexicanAmericans (Riolo et al., 2005). In contrast, the results of some studies revealed no differences in the prevalence of depression among races (Chen et al., 2011; Weisbord et al., 2007b). Balakrishnan et al. (2004) demonstrated that single nucleotide polymorphisms in the promoter region of the proinflammatory cytokines appear to have a strong association with indices of comorbidity, biological and nutritional markers. Whether depression is associated with a genetic predisposition for racial differences or cytokine gene polymorphisms warrants further investigation.

Other studies have evaluated the possible effects of dialysis materials on depression. Peritoneal dialysis (PD) patients have been noted to have less severe anxiety, insomnia, and depression than do HD patients (Ginieri-Coccossis et al., 2008; Noshad et al., 2009). It has been suggested that the rate of depression is greater among patients using cellulosederivative dialyzers than among those using polysulfone dialyzers (Hsu et al., 2009). Using PD or more biocompatible dialyzers thus might be associated with better mental health in HD patients.

\subsection{Psychological and social factors for depression}

A number of studies have focused upon the effects of HD patients, including feelings of hopelessness, perceptions of loss and lack of control, job loss, and altered family and social relationships (Kimmel, 2001). Because ESRD is a lifelong disease, feelings of lack of control and perceptions of overwhelming illness might be inevitable. The intrusiveness of these thoughts is related to depression (Christensen \& Ehlers, 2002; Devins et al., 1997).

More recent work has focused upon the possible effects of underlying illness upon depressive symptoms among ESRD patients (Guzman \& Nicassio, 2003). Perception of loss has been regarded as a strong predictor of depression (Chan et al., 2009), which in turn predicts mortality (Chilcot et al., 2011). In terms of the risk by demographic characteristics, results have been inconsistent (Taskapan et al., 2005). It was reported that depression among dialysis patients increased with increasing age and lower educational levels (Keskin \& Engin, 2011). In some studies, depressive symptoms were more common among women, and increased with unemployment and also rose among patients with higher comorbidity of physical diseases (Araujo et al., 2011; Chen et al., 2010; Ibrahim \& El Salamony, 2008). Thus, negative cognition and lack of social support might exacerbate patients' negative feelings, and thus further contribute to depression.

\section{Anxiety}

Anxiety is also commonly seen in HD patients (Kring \& Crane, 2009). Cukor et al. demonstrated a $27 \%$ incidence of anxiety among 70 urban HD patients, which was somewhat higher than the $18 \%$ incidence reported in a national survey (Kessler et al., 2005). During a 16-month follow-up study, $9 \%$ of patients had both anxiety and depression at baseline; the incidence of both conditions rose to $13 \%$ by the end of the study. At the end of the study, two-thirds of individuals with comorbid depression and anxiety at baseline had both diagnoses (Cukor et al., 2008b). Furthermore, Cukor et al. (2008a) reported that 45.7\% 
of a group of dialysis patients recruited from a single center met criteria for an anxiety disorder. The most prevalent disorders were specific phobias $(26.6 \%)$ and panic disorder $(21.0 \%)$. Bossola et al. (2010) indicated that $47.5 \%$ of $80 \mathrm{HD}$ patients had mild symptoms of anxiety, while $48.7 \%$ had moderate or severe symptoms of anxiety. In addition, the anxiety scores correlated significantly with age and comorbidities, and anxiety were commonly noted in patients with poor appetite (Bossola et al., 2011). A review of 55 studies that investigated symptoms of anxiety in ESRD patients found that $12 \%$ to $52 \%$ of patients with ESRD had substantial anxiety (Murtagh et al., 2007).

In one of our previous studies, $21 \%$ of dialysis patients had symptoms of anxiety. In addition, $15.5 \%$ of these subjects had comorbid depression and anxiety, and $44.3 \%$ of depressed patients had comorbid anxiety (Chen et al., 2010). Furthermore, suicide risk was not only attributed to depression, but also to anxiety.

The call for depression screening in HD patients is growing, but screening for anxiety in patients with ESRD population is relatively disregarded. This is an indication that many clinicians underestimate the importance of anxiety among HD patients. O'Donovan et al. (2010) reported that clinically anxious participants exhibited significantly lower levels of morning cortisol and significantly higher levels of IL-6, compared with non-anxious participants. Uncertainty about the future and fear of losing control of one's life are important factors associated with anxiety that adversely impact emotional stability (Haenel et al., 1980). Notably, anxiety is a common psychological problem that may emerge during the initial course of dialysis (Cukor et al., 2008b), and is a reminder to clinicians to pay close attention to this issue.

\section{Fatigue}

Fatigue is a subjective symptom characterized by tiredness, weakness, and lack of energy.(Lee et al., 1991) Fatigue is also one of the most debilitating symptoms reported by HD patients, and roughly $60 \%$ to $97 \%$ of patients on HD experience some degree of it (Jhamb et al., 2008). People with chronic renal disease, regardless of whether they are predialysis or receiving either HD or PD, are reported having high levels of fatigue and are often unable to engage in normal daily activities (Bonner et al., 2010). In addition, fatigue is positively correlated with depression (Chen et al., 2010; Sklar et al., 1996), and negatively correlated with QoL (Lee et al., 2007). In one study, researchers noted a significant relationship between the duration of treatment and the level of fatigue. The experience of fatigue was more commonly reported in respondents who had been receiving treatment for more than 2 years, compared to those treated for less than 2 years (Letchmi et al., 2011). In a longitudinal analysis of 917 incident HD and PD patients, those with lower levels of fatigue at baseline survived longer (Jhamb et al., 2009).

Factors that may contribute to fatigue in dialysis patients include anemia, malnutrition, inflammation, depression and/or sleep disorders (Jhamb et al., 2008). Anemia resulting from reduced erythropoietin production has been cited as an important cause of fatigue in this population (Singh et al., 2006). Additionally, patients undergoing chronic HD show evidence of accelerated protein catabolism, which might be due to the significant loss of amino acids induced by dialysis (Pertosa et al., 2000). Thus, it is reasonable to presume that lower levels of albumin can be significantly correlated with greater levels of fatigue (Bonner 
et al., 2010). Malnutrition in dialysis patients might also be related to poor intake, or the result of chronic inflammation (Stenvinkel et al., 1999). Cytokines productions, particularly IL-6, might induce protein catabolism and lipolysis (Memoli et al., 2002), and cytokines have a strong negative correlation with serum albumin levels in HD patients (Montinaro et al., 2010). Thus, chronic inflammation and malnutrition might result in fatigue by either directly activating the central nervous system through adrenal axis or by indirectly triggering multisystem deregulation (Jhamb et al., 2008).

\section{Decreased Quality of Life (QoL)}

Health-related QoL is an important measure of how a disease affects the lives of patients. The QoL domains include physical, psychological, and social functioning and general satisfaction with life (Tsay \& Healstead, 2002). Once patients with ESRD start to receive HD, they must face the chronic stress related to restrictions on their time, the economical and vocational costs related to treatment, functional limitations, dietary constraints, and possible adverse effects of medications (Son et al., 2009). Numerous studies have demonstrated that these patients have a lower QoL than that of healthy populations (Kao et al., 2009; Perlman et al., 2005; Wolcott et al., 1988). Depression is strongly correlated with decreased healthrelated QoL, especially in mental dimensions (Chen et al., 2010; Kao et al., 2009). Furthermore, several studies have shown that patients with poorer QoL had a higher incidence of anxiety and fatigue (Kring \& Crane, 2009), and longitudinal follow-up showed increased mortality (Drayer et al., 2006; Wolcott et al., 1988).

Biological function, mental illnesses, general health perception, and characteristics of the individual and environment may contribute to the variability in patients' QoL (Kring \& Crane, 2009). Biological factors that have been associated with QoL include altered hemoglobin, albumin, ferritin, CRP, IL-6, IL-8, and TNF-a levels (Farag et al., 2011; Kalender et al., 2007a; Montinaro et al., 2010; Perlman et al., 2005). Poor exercise tolerance and muscle weakness may limit daily activity, again causing poor QoL (Hsieh et al., 2007; Sakkas et al., 2003). However, Barros et al. (2011) suggested there was no association of nutritional status with malnutrition-inflammation, QoL, or depressive symptoms. There is still debate about whether patients' QoL can be directly correlated to malnutrition-inflammation markers.

Among psychological issues, uncertainty about the future and lack of energy emerged as the major contributors to poor QoL (Tsay \& Healstead, 2002). A patient's dependency on treatment may negatively impact his or her QoL and exacerbate feelings of a loss of control (Chilcot et al., 2008). Improved QoL is correlated with higher self-esteem and lower levels of mood disturbances (Wolcott et al., 1988). Furthermore, time of diagnosis of chronic renal failure may be an important factor related to the QoL of patients receiving dialysis. Late diagnosis of renal failure and the consequent lack of predialysis care adversely affect QoL among these patients (Sesso \& Yoshihiro, 1997). Therefore, early detection of renal failure and identification of underlying mental illnesses might be important issues for establishing better QoL in HD patients.

\section{Suicide}

Suicide may be the most serious result of mental illness among HD patients. Kurella et al. (2005) reported the death rate from suicide was $0.24 \%$ per 1000 dialysis patients-years at 
risk. Patients with ESRD had a significantly higher rate of suicide compared with the general population in the United States. Chen et al. (2010) demonstrated that among 200 patients with HD, $21.5 \%$ had suicidal ideation; $3.5 \%$ had planned a suicide attempt in prior months; and 3.5\% had attempted suicide during their lifetime. It is noteworthy that an increased number of patients with ESRD had withdrawn from dialysis before their death. Nevertheless, only a small proportion $(12 \%)$ of the respondents were unsure or believed that discontinuing dialysis was the equivalent of suicide (Cohen et al., 2002). If the data on withdrawal from dialysis were factored into current epidemiologic investigations, the suicide rate among HD patients might be much greater.

Suicide was associated with several demographic characteristics among HD patients. Independent predictors of suicide included old age, male gender, lower educational status, alcohol or drug dependence, and recent hospitalization for mental illness (Keskin \& Engin, 2011; Kurella et al., 2005). Having strong religious beliefs has been suggested as one protective factor of suicide risk among HD patients (Martiny et al., 2011). Preexisting depression and anxiety disorders have been identified as independent risk factors for subsequent onset of suicidal ideation and attempts in the general population (Martiny et al., 2011; Sareen et al., 2005). Specific for HD patients, suicide risk was also significantly predicted by anxiety and depression. On the other hand, fatigue and QoL may not directly affect suicide risk (Chen et al., 2010). Because suicide might be preventable via early detection of warning signs, it is crucial to identify the psychological impact and possible risk of suicide among dialysis patients.

\section{Managing the psychological impact on dialysis patients}

Numerous studies investigated the managements for mental illness in HD patients, including pharmacological and non-pharmacological interventions (Table 2).

\subsection{Pharmacological interventions}

Today, selective serotonin reuptake inhibitors (SSRIs) are the treatment of choice for HD patients with depression or anxiety (Raymond et al., 2008). Fluoxetine has been effective and safe in HD patients, although trials have thus far involved only small numbers of patients (Blumenfield et al., 1997). Citalpram, which is similar to fluoxetine in treatment effects, is thought to be safe (Cohen et al., 2004), and it has been beneficial for improving QoL in HD patients (Kalender et al., 2007b). Paroxetine, combined with supportive psychotherapy, has been shown to be not only successful for treating depression, but also for improving nutritional status in chronic HD patients with depression (Koo et al., 2005). Sertraline has safe pharmacokinetics in patients with ESRD, and treatment with sertraline in PD patients is associated with improved of QoL and fewer symptoms of depression (Atalay et al., 2010). Duloxetine and venlafaxine, which are categorized as serotonin-norepinephrine reuptake inhibitors, are beneficial for patients with major depressive disorder (Ye et al., 2011). However, these agents' safety and efficacy have not been specifically established for HD patients. Bupropion, a dopamine-norepinephrine reuptake inhibitor, and mirtazapine, a noradrenergic and specific serotonergic, have also been widely used for patients with depression. However, once again, it is not clear whether the beneficial effects of these agents can be generalized to dialysis patients. Generally, older tricyclic medications have an adverse cardiac profile and anticholinergic effects, which limits their use for HD patients 


\begin{tabular}{|c|c|c|c|}
\hline Treatment & $\begin{array}{c}\text { Target } \\
\text { Symptoms }\end{array}$ & Side Effects & Clini \\
\hline \multicolumn{4}{|l|}{ Pharmacological interventions } \\
\hline $\begin{array}{l}\text { Selective serotonin reuptake inhibitors } \\
\text { (fluoxetine, citalopram, paroxetine, } \\
\text { sertraline) }\end{array}$ & $\begin{array}{l}\text { Depression } \\
\text { Anxiety }\end{array}$ & $\begin{array}{l}\text { Gastrointestinal symptoms, } \\
\text { sexual dysfunction, risk of } \\
\text { bleeding, suicidal ideation }\end{array}$ & $\begin{array}{l}\text { Fluoxetine } \\
\text { Citaloprar } \\
\text { severe ren } \\
\text { patients. } \\
\text { Paroxetin }\end{array}$ \\
\hline $\begin{array}{l}\text { Serotonin-norepinephrine reuptake } \\
\text { inhibitors (venlafaxine, duloxetine) }\end{array}$ & Depression & $\begin{array}{l}\text { Accumulation of toxic } \\
\text { metabolites, sexual } \\
\text { dysfunction, hypertension }\end{array}$ & $\begin{array}{l}\text { Decrease } 1 \\
\text { in mild-to } \\
\text { impairme }\end{array}$ \\
\hline $\begin{array}{l}\text { Dopamine-norepinephrine reuptake } \\
\text { inhibitors } \\
\text { (bupropion) }\end{array}$ & $\begin{array}{l}\text { Depression } \\
\text { Fatigue }\end{array}$ & $\begin{array}{l}\text { Insomnia, agitation, seizure, } \\
\text { accumulation of toxic } \\
\text { metabolites }\end{array}$ & $\begin{array}{l}\text { Use with } \\
\text { reduction } \\
\text { impairme }\end{array}$ \\
\hline $\begin{array}{l}\text { Noradrenergic and specific } \\
\text { serotonergics } \\
\text { (mirtazapine) }\end{array}$ & Depression & $\begin{array}{l}\text { Sedation, somnolence, } \\
\text { weight gain }\end{array}$ & Reduce \\
\hline $\begin{array}{l}\text { Tricyclics and tetracyclics } \\
\text { (amitriptyline, desipramine,doxepin, } \\
\text { nortriptyline) }\end{array}$ & Depression & $\begin{array}{l}\text { Anticholinergic effects, } \\
\text { sedation, } \\
\text { QTc prolongation, cardiac } \\
\text { arrhythmias, orthostatic } \\
\text { hypotension }\end{array}$ & $\begin{array}{l}\text { Avoid if } \mathrm{p} \\
\text { side effect }\end{array}$ \\
\hline $\begin{array}{l}\text { Serotonin modulators } \\
\text { (netazodone, trazodone) }\end{array}$ & Depression & $\begin{array}{l}\text { Accumulation of toxic } \\
\text { metabolites, liver failure (for } \\
\text { nefazodone), sedation, } \\
\text { hypotension, cardiac } \\
\text { arrhythmias }\end{array}$ & $\begin{array}{l}\text { Avoid use } \\
\text { cardiac di }\end{array}$ \\
\hline Erythropoietin & $\begin{array}{l}\text { Fatigue } \\
\text { Quality of life }\end{array}$ & $\begin{array}{l}\text { Seizures, increased clotting, } \\
\text { and influenza-like } \\
\text { syndromes }\end{array}$ & $\begin{array}{l}\text { No signifi } \\
\text { between o } \\
\text { thrice-wee } \\
\text { administr: }\end{array}$ \\
\hline
\end{tabular}




\begin{tabular}{|c|c|c|}
\hline Treatment & $\begin{array}{c}\text { Target } \\
\text { Symptoms }\end{array}$ & Side Effects \\
\hline \multicolumn{3}{|l|}{ Pharmacological interventions } \\
\hline $\begin{array}{l}\text { Partial Serotonin } 5 \mathrm{HT}(1 \mathrm{~A}) \text { receptor } \\
\text { agonists } \\
\text { (buspirone) }\end{array}$ & Anxiety & $\begin{array}{l}\text { Dizziness, nausea, headache, } \\
\text { insomnia, tremor }\end{array}$ \\
\hline $\begin{array}{l}\text { Benzodiazepines } \\
\text { (alprazolam, lorazepam, diazepam, } \\
\text { midazolam, chlordiazepoxide) }\end{array}$ & $\begin{array}{l}\text { Anxiety } \\
\text { Insomnia }\end{array}$ & $\begin{array}{l}\text { Prolong sedation, physical } \\
\text { and psychological } \\
\text { dependence, cognition } \\
\text { impairment, withdrawal } \\
\text { symptoms }\end{array}$ \\
\hline \multicolumn{3}{|l|}{ Non-pharmacological interventions } \\
\hline Cognitive behavior therapy (CBT) & $\begin{array}{l}\text { Depression } \\
\text { Quality of life }\end{array}$ & $\begin{array}{l}\text { Takes longer time to reach } \\
\text { effects than pharmacological } \\
\text { treatment }\end{array}$ \\
\hline Exercise training & $\begin{array}{l}\text { Depression } \\
\text { Quality of life }\end{array}$ & $\begin{array}{l}\text { No serious adverse effects } \\
\text { were reported }\end{array}$ \\
\hline Acupuncture & Quality of life & $\begin{array}{l}\text { No serious adverse effects } \\
\text { were reported }\end{array}$ \\
\hline $\begin{array}{l}\text { Social support, marital, family } \\
\text { counseling }\end{array}$ & $\begin{array}{l}\text { Depression } \\
\text { Spousal } \\
\text { depression }\end{array}$ & $\begin{array}{l}\text { No serious adverse effects } \\
\text { were reported. }\end{array}$ \\
\hline
\end{tabular}


In summary, with the exception of the SSRIs, the efficacy and safety of antidepressant drug therapy in dialysis patients have not been clearly established, although these medications are believed to improve depression empirically. Notably, the relative activity and mode of excretion of metabolites of antidepressants in dialysis patients are as yet unknown and may complicate the use of these drugs if adverse events occur. It also remains unclear whether there are potential drug-drug interactions between antidepressants and other drugs commonly used in HD patients. Therefore, the general rule for prescribing antidepressants among HD patients is to start at a lower dose and increase the dosage gradually (Cohen et al., 2004).

There is evidence that the use of erythropoietin-stimulating agents might reduce fatigue and improve QoL among ESRD patients (Jones et al., 2004). Benzodiazepines (BZD), such as diazepam, alprazolam, and lorazepam, have been successfully used to relieve acute episodes of panic and anxiety. In addition, BZD are also widely prescribed for HD patients with insomnia (Wyne et al., 2011). In recent years, the use of non-BZD drugs such as zolpidem, zopiclone, and zaleplon for insomnia patients has rapidly increased. However, it is noteworthy that the liability for abuse and dependence exist in both BZD and non-BZD drugs, especially with long-term use (Victorri-Vigneau et al., 2007). Buspirone, a partial serotonin agonist that acts on the $5 \mathrm{HT}(1 \mathrm{~A})$ receptor, is often recommended for patients with anxiety, and it is generally is considered to have fewer unfavorable side effects than does BZD. Generally, it is not necessary to adjust the dosage of most of the erythropoietinstimulating agents we have mentioned for the level of the glomerular filtation rate, for these agents are metabolized in the liver (Hedayati \& Finkelstein, 2009). However, buspirone and lorazepam may take longer to be eliminated in ESRD patients, and thus the dosage of these two drugs should be carefully titrated. Notably, Winkelmayer et al. (2007) reported that BZD or zolpidem are commonly used for incident dialysis patients and may be associated with greater mortality in this group. Although the causal reference to this effect warrants further investigation, it is also a warning that clinicians need to consider the necessity of long-term use of BZD in dialysis patients.

\subsection{Non-pharmacological interventions}

Psychotherapy has been used for a wide range of chronic illnesses, including patients with HD (Hedayati \& Finkelstein, 2009). Of these approaches, cognitive behavioral therapy (CBT), a well-documented evidence-based therapy for depression, has been shown to be effective (Chen et al., 2011; Duarte et al., 2009). CBT is based on the assumption that one's dysfunctional "automatic thoughts" in response to a situation can result in strong negative feelings/emotions, and thus lead to depression. Correction of those faulty dysfunctional constructs can lead to clinical improvement. Duarte et al. (2009) demonstrated that CBT performed during 3-month-long group therapy is effective for improving depression and many dimensions of QoL in chronic HD patients. Chen et al. (2011) conducted a randomized controlled interventional study of 72 sleep-disturbed HD patients. Compared with the control group (who received sleep health education), patients who received CBT had significant improvements in sleep quality, fatigue, depression, and anxiety. Interestingly, CRP, IL-18, and oxidized low-density lipoprotein levels also significantly declined among those receiving CBT in comparison to those in the control group (Chen et al., 2011). Thus, 
these studies suggest that CBT might be effective for improving mental health, and for reducing inflammation and oxidative stress in HD patients.

Exercise programs may have a beneficial effect on depressive symptoms in patients with ESRD. Ouzouni et al. (2009) reported that 10-month intradialytic exercise training improved QoL in both physical functioning and psychological status in HD patients, and decreased in self-reported depression. In another study, a 1-year exercise training program reduced emotional distress and concomitantly improved cardiac autonomic modulation measured by heart rate variability (HRV) indices (Kouidi et al., 2010). For alternative therapy, Kim et al. (2011) reported that $24 \mathrm{HD}$ patients who received individualized acupuncture treatments over 6 consecutive weeks showed significant improvements in some QoL subscales.

Social support has been shown to help improve emotional disturbances in a variety of chronic illnesses. Support and education, either individually to patients or including their caregivers and family members, may be helpful (Symister \& Friend, 2003). A patient's depression could be influenced by the psychosocial status of his or her spouse, and the spouse might be amenable to interventions that could improve patient outcome (Daneker et al., 2001). Social support has been shown to decrease depression by improving the selfesteem of patients with ESRD, which led to increased optimism (Symister \& Friend, 2003). Treatment programs that address problems with social interactions of patients need to be comprehensive, and should explore use of family and marital counseling, and involvement of the community, along with consideration of the patient's social life (Cohen et al., 2007).

\section{Conclusion}

$\mathrm{HD}$ is a life-sustaining treatment for patients with ESRD; however, it adversely affects patients' mental status. Increasingly, depression is being recognized as a substantial comorbid illness in these patients. Anxiety, feelings of fatigue, and decreasing QoL are also significant psychological symptoms, and they may be interrelated. Depression and anxiety particularly increase patients' suicide risk. Mental illnesses may have underlying biological and psychological causes. There is considerable evidence that these psychological effects are associated with adverse outcomes in HD patients with ESRD. It is important, therefore, to develop systematic approaches to screening patients for mental illness, and then planning treatment strategies. To improve treatment outcome and patient Qol, a comprehensive management plan that includes pharmacological and psychosocial interventions, is essential.

\section{References}

Abbas Tavallaii, S., Ebrahimnia, M., Shamspour, N. \& Assari, S. (2009). Effect of depression on health care utilization in patients with end-stage renal disease treated with hemodialysis. Eur J Intern Med, 20, 411-414

Agrawal, S., Gollapudi, P., Elahimehr, R., Pahl, M.V. \& Vaziri, N.D. (2010). Effects of endstage renal disease and haemodialysis on dendritic cell subsets and basal and LPSstimulated cytokine production. Nephrol Dial Transplant, 25, 737-746 
Araujo, S.M., De Bruin, V.M., Daher, E.D., Almeida, G.H., Medeiros, C.A. \& De Bruin, P.F. (2011). Risk factors for depressive symptoms in a large population on chronic hemodialysis. Int Urol Nephrol (In press)

Atalay, H., Solak, Y., Biyik, M., Biyik, Z., Yeksan, M., Uguz, F., et al. (2010). Sertraline treatment is associated with an improvement in depression and health-related quality of life in chronic peritoneal dialysis patients. Int Urol Nephrol, 42, 527-536

Balakrishnan, V.S., Guo, D., Rao, M., Jaber, B.L., Tighiouart, H., Freeman, R.L., et al. (2004). Cytokine gene polymorphisms in hemodialysis patients: association with comorbidity, functionality, and serum albumin. Kidney Int, 65, 1449-1460

Barros, A., Da Costa, B.E., Poli-De-Figueiredo, C.E., Antonello, I.C. \& D'avila, D.O. (2011). Nutritional status evaluated by multi-frequency bioimpedance is not associated with quality of life or depressive symptoms in hemodialysis patients. Ther Apher Dial, 15, 58-65

Blumenfield, M., Levy, N.B., Spinowitz, B., Charytan, C., Beasley, C.M., Jr., Dubey, A.K., et al. (1997). Fluoxetine in depressed patients on dialysis. Int J Psychiatry Med, 27, 71-80

Bonner, A., Wellard, S. \& Caltabiano, M. (2010). The impact of fatigue on daily activity in people with chronic kidney disease. J Clin Nurs, 19, 3006-3015

Bossola, M., Ciciarelli, C., Di Stasio, E., Conte, G.L., Vulpio, C., Luciani, G., et al. (2010). Correlates of symptoms of depression and anxiety in chronic hemodialysis patients. Gen Hosp Psychiatry, 32, 125-131

Bossola, M., Ciciarelli, C., Di Stasio, E., Panocchia, N., Conte, G.L., Rosa, F., et al. (2011). Relationship between Appetite and Symptoms of Depression and Anxiety in Patients on Chronic Hemodialysis. J Ren Nutr (In press)

Bossola, M., Luciani, G. \& Tazza, L. (2009). Fatigue and its correlates in chronic hemodialysis patients. Blood Purif, 28, 245-252

Capuron, L. \& Miller, A.H. (2011). Immune system to brain signaling: neuropsychopharmacological implications. Pharmacol Ther, 130, 226-238

Chan, R., Brooks, R., Erlich, J., Chow, J. \& Suranyi, M. (2009). The effects of kidney-diseaserelated loss on long-term dialysis patients' depression and quality of life: positive affect as a mediator. Clin J Am Soc Nephrol, 4, 160-167

Chen, C.K., Tsai, Y.C., Hsu, H.J., Wu, I.W., Sun, C.Y., Chou, C.C., et al. (2010). Depression and suicide risk in hemodialysis patients with chronic renal failure. Psychosomatics, $51,528-528$ e526

Chen, H.Y., Cheng, I.C., Pan, Y.J., Chiu, Y.L., Hsu, S.P., Pai, M.F., et al. (2011). Cognitivebehavioral therapy for sleep disturbance decreases inflammatory cytokines and oxidative stress in hemodialysis patients. Kidney Int, 80, 415-422

Chilcot, J., Wellsted, D., Da Silva-Gane, M. \& Farrington, K. (2008). Depression on dialysis. Nephron Clin Pract, 108, c256-264

Chilcot, J., Wellsted, D. \& Farrington, K. (2011). Illness perceptions predict survival in haemodialysis patients. Am J Nephrol, 33, 358-363

Christensen, A.J. \& Ehlers, S.L. (2002). Psychological factors in end-stage renal disease: an emerging context for behavioral medicine research. J Consult Clin Psychol, 70, 712724 
Cohen, L.M., Dobscha, S.K., Hails, K.C., Pekow, P.S. \& Chochinov, H.M. (2002). Depression and suicidal ideation in patients who discontinue the life-support treatment of dialysis. Psychosom Med, 64, 889-896

Cohen, L.M., Tessier, E.G., Germain, M.J. \& Levy, N.B. (2004). Update on psychotropic medication use in renal disease. Psychosomatics, 45, 34-48

Cohen, S.D., Sharma, T., Acquaviva, K., Peterson, R.A., Patel, S.S. \& Kimmel, P.L. (2007). Social support and chronic kidney disease: an update. Adv Chronic Kidney Dis, 14, 335-344

Collins, A.J., Foley, R.N., Herzog, C., Chavers, B., Gilbertson, D., Ishani, A., et al. (2009). United States Renal Data System 2008 Annual Data Report. Am J Kidney Dis, 53, S1374

Cukor, D., Coplan, J., Brown, C., Friedman, S., Cromwell-Smith, A., Peterson, R.A., et al. (2007). Depression and anxiety in urban hemodialysis patients. Clin J Am Soc Nephrol, 2, 484-490

Cukor, D., Coplan, J., Brown, C., Friedman, S., Newville, H., Safier, M., et al. (2008a). Anxiety disorders in adults treated by hemodialysis: a single-center study. Am J Kidney Dis, 52, 128-136

Cukor, D., Coplan, J., Brown, C., Peterson, R.A. \& Kimmel, P.L. (2008b). Course of depression and anxiety diagnosis in patients treated with hemodialysis: a 16-month follow-up. Clin J Am Soc Nephrol, 3, 1752-1758

Czira, M.E., Lindner, A.V., Szeifert, L., Molnar, M.Z., Fornadi, K., Kelemen, A., et al. (2011). Association between the Malnutrition-Inflammation Score and depressive symptoms in kidney transplanted patients. Gen Hosp Psychiatry, 33, 157-165

Daneker, B., Kimmel, P.L., Ranich, T. \& Peterson, R.A. (2001). Depression and marital dissatisfaction in patients with end-stage renal disease and in their spouses. Am J Kidney Dis, 38, 839-846

Devins, G.M., Beiser, M., Dion, R., Pelletier, L.G. \& Edwards, R.G. (1997). Cross-cultural measurements of psychological well-being: the psychometric equivalence of Cantonese, Vietnamese, and Laotian translations of the Affect Balance Scale. Am J Public Health, 87, 794-799

Doweiko, J., Fogel, B.S. \& Goldberg, R.J. (1984). Trazodone and hemodialysis. J Clin Psychiatry, 45, 361

Drayer, R.A., Piraino, B., Reynolds, C.F., 3rd, Houck, P.R., Mazumdar, S., Bernardini, J., et al. (2006). Characteristics of depression in hemodialysis patients: symptoms, quality of life and mortality risk. Gen Hosp Psychiatry, 28, 306-312

Duarte, P.S., Miyazaki, M.C., Blay, S.L. \& Sesso, R. (2009). Cognitive-behavioral group therapy is an effective treatment for major depression in hemodialysis patients. Kidney Int, 76, 414-421

Farag, Y.M., Keithi-Reddy, S.R., Mittal, B.V., Surana, S.P., Addabbo, F., Goligorsky, M.S., et al. (2011). Anemia, inflammation and health-related quality of life in chronic kidney disease patients. Clin Nephrol, 75, 524-533

Feroze, U., Martin, D., Reina-Patton, A., Kalantar-Zadeh, K. \& Kopple, J.D. (2010). Mental health, depression, and anxiety in patients on maintenance dialysis. Iran J Kidney Dis, 4, 173-180

Gill, J., Luckenbaugh, D., Charney, D. \& Vythilingam, M. (2010). Sustained elevation of serum interleukin-6 and relative insensitivity to hydrocortisone differentiates 
posttraumatic stress disorder with and without depression. Biol Psychiatry, 68, 9991006

Ginieri-Coccossis, M., Theofilou, P., Synodinou, C., Tomaras, V. \& Soldatos, C. (2008). Quality of life, mental health and health beliefs in haemodialysis and peritoneal dialysis patients: investigating differences in early and later years of current treatment. BMC Nephrol, 9, 14

Group, T.W. (1998). Development of the World Health Organization WHOQOL-BREF quality of life assessment. The WHOQOL Group. Psychol Med, 28, 551-558

Guzman, S.J. \& Nicassio, P.M. (2003). The contribution of negative and positive illness schemas to depression in patients with end-stage renal disease. J Behav Med, 26, 517-534

Haenel, T., Brunner, F. \& Battegay, R. (1980). Renal dialysis and suicide: occurrence in Switzerland and in Europe. Compr Psychiatry, 21, 140-145

Hedayati, S.S., Bosworth, H.B., Briley, L.P., Sloane, R.J., Pieper, C.F., Kimmel, P.L., et al. (2008). Death or hospitalization of patients on chronic hemodialysis is associated with a physician-based diagnosis of depression. Kidney Int, 74, 930-936

Hedayati, S.S. \& Finkelstein, F.O. (2009). Epidemiology, diagnosis, and management of depression in patients with CKD. Am J Kidney Dis, 54, 741-752

Howren, M.B., Lamkin, D.M. \& Suls, J. (2009). Associations of depression with C-reactive protein, IL-1, and IL-6: a meta-analysis. Psychosom Med, 71, 171-186

Hsieh, R.L., Lee, W.C., Huang, H.Y. \& Chang, C.H. (2007). Quality of life and its correlates in ambulatory hemodialysis patients. J Nephrol, 20, 731-738

Hsu, H.J., Chen, C.K. \& Wu, M.S. (2009). Lower prevalence of depression in hemodialysis patients who use polysulfone dialyzers. Am J Nephrol, 29, 592-597

Huang, T.L. \& Lee, C.T. (2007). Low serum albumin and high ferritin levels in chronic hemodialysis patients with major depression. Psychiatry Res, 152, 277-280

Hung, K.C., Wu, C.C., Chen, H.S., Ma, W.Y., Tseng, C.F., Yang, L.K., et al. (2011). Serum IL6 , albumin and co-morbidities are closely correlated with symptoms of depression in patients on maintenance haemodialysis. Nephrol Dial Transplant, 26, 658-664

Ibrahim, S. \& El Salamony, O. (2008). Depression, quality of life and malnutritioninflammation scores in hemodialysis patients. Am J Nephrol, 28, 784-791

Irwin, M.R. \& Miller, A.H. (2007). Depressive disorders and immunity: 20 years of progress and discovery. Brain Behav Immun, 21, 374-383

Jhamb, M., Argyropoulos, C., Steel, J.L., Plantinga, L., Wu, A.W., Fink, N.E., et al. (2009). Correlates and outcomes of fatigue among incident dialysis patients. Clin J Am Soc Nephrol, 4, 1779-1786

Jhamb, M., Weisbord, S.D., Steel, J.L. \& Unruh, M. (2008). Fatigue in patients receiving maintenance dialysis: a review of definitions, measures, and contributing factors. Am J Kidney Dis, 52, 353-365

Jones, M., Ibels, L., Schenkel, B. \& Zagari, M. (2004). Impact of epoetin alfa on clinical end points in patients with chronic renal failure: a meta-analysis. Kidney Int, 65, 757767

Kalender, B., Ozdemir, A.C., Dervisoglu, E. \& Ozdemir, O. (2007a). Quality of life in chronic kidney disease: effects of treatment modality, depression, malnutrition and inflammation. Int J Clin Pract, 61, 569-576 
Kalender, B., Ozdemir, A.C., Yalug, I. \& Dervisoglu, E. (2007b). Antidepressant treatment increases quality of life in patients with chronic renal failure. Ren Fail, 29, 817-822

Kao, T.W., Lai, M.S., Tsai, T.J., Jan, C.F., Chie, W.C. \& Chen, W.Y. (2009). Economic, social, and psychological factors associated with health-related quality of life of chronic hemodialysis patients in northern Taiwan: a multicenter study. Artif Organs, 33, 61-68

Keskin, G. \& Engin, E. (2011). The evaluation of depression, suicidal ideation and coping strategies in haemodialysis patients with renal failure. J Clin Nurs (In press)

Kessler, R.C., Berglund, P., Demler, O., Jin, R., Koretz, D., Merikangas, K.R., et al. (2003). The epidemiology of major depressive disorder: results from the National Comorbidity Survey Replication (NCS-R). JAMA, 289, 3095-3105

Kessler, R.C., Chiu, W.T., Demler, O., Merikangas, K.R. \& Walters, E.E. (2005). Prevalence, severity, and comorbidity of 12-month DSM-IV disorders in the National Comorbidity Survey Replication. Arch Gen Psychiatry, 62, 617-627

Kim, K.H., Kim, T.H., Kang, J.W., Sul, J.U., Lee, M.S., Kim, J.I., et al. (2011). Acupuncture for symptom management in hemodialysis patients: a prospective, observational pilot study. J Altern Complement Med, 17, 741-748

Kimmel, P.L. (2001). Psychosocial factors in dialysis patients. Kidney Int, 59, 1599-1613

Kimmel, P.L. \& Peterson, R.A. (2005). Depression in end-stage renal disease patients treated with hemodialysis: tools, correlates, outcomes, and needs. Semin Dial, 18, 91-97

Kimmel, P.L., Phillips, T.M., Simmens, S.J., Peterson, R.A., Weihs, K.L., Alleyne, S., et al. (1998). Immunologic function and survival in hemodialysis patients. Kidney Int, 54, 236-244

Kimmel, P.L., Weihs, K. \& Peterson, R.A. (1993). Survival in hemodialysis patients: the role of depression. J Am Soc Nephrol, 4, 12-27

Koo, J.R., Yoon, J.W., Kim, S.G., Lee, Y.K., Oh, K.H., Kim, G.H., et al. (2003). Association of depression with malnutrition in chronic hemodialysis patients. Am J Kidney Dis, 41, 1037-1042

Koo, J.R., Yoon, J.Y., Joo, M.H., Lee, H.S., Oh, J.E., Kim, S.G., et al. (2005). Treatment of depression and effect of antidepression treatment on nutritional status in chronic hemodialysis patients. Am J Med Sci, 329, 1-5

Kouidi, E., Karagiannis, V., Grekas, D., Iakovides, A., Kaprinis, G., Tourkantonis, A., et al. (2010). Depression, heart rate variability, and exercise training in dialysis patients. Eur J Cardiovasc Prev Rehabil, 17, 160-167

Kring, D.L. \& Crane, P.B. (2009). Factors affecting quality of life in persons on hemodialysis. Nephrol Nurs J, 36, 15-24, 55

Kuo, H.W., Tsai, S.S., Tiao, M.M. \& Yang, C.Y. (2007). Epidemiological features of CKD in Taiwan. Am J Kidney Dis, 49, 46-55

Kurella, M., Kimmel, P.L., Young, B.S. \& Chertow, G.M. (2005). Suicide in the United States end-stage renal disease program. J Am Soc Nephrol, 16, 774-781

Lee, B.O., Lin, C.C., Chaboyer, W., Chiang, C.L. \& Hung, C.C. (2007). The fatigue experience of haemodialysis patients in Taiwan. J Clin Nurs, 16, 407-413

Lee, K.A., Hicks, G. \& Nino-Murcia, G. (1991). Validity and reliability of a scale to assess fatigue. Psychiatry Res, 36, 291-298

Leonard, B.E. (2010). The concept of depression as a dysfunction of the immune system. Curr Immunol Rev, 6, 205-212 
Letchmi, S., Das, S., Halim, H., Zakariah, F.A., Hassan, H., Mat, S., et al. (2011). Fatigue experienced by patients receiving maintenance dialysis in hemodialysis units. Nurs Health Sci, 13, 60-64

Loftis, J.M., Huckans, M. \& Morasco, B.J. (2010). Neuroimmune mechanisms of cytokineinduced depression: current theories and novel treatment strategies. Neurobiol Dis, $37,519-533$

Martiny, C., De Oliveira, E.S.A.C., Neto, J.P. \& Nardi, A.E. (2011). Factors associated with risk of suicide in patients with hemodialysis. Compr Psychiatry, 52, 465-468

Memoli, B., Minutolo, R., Bisesti, V., Postiglione, L., Conti, A., Marzano, L., et al. (2002). Changes of serum albumin and C-reactive protein are related to changes of interleukin-6 release by peripheral blood mononuclear cells in hemodialysis patients treated with different membranes. Am J Kidney Dis, 39, 266-273

Montinaro, V., Iaffaldano, G.P., Granata, S., Porcelli, P., Todarello, O., Schena, F.P., et al. (2010). Emotional symptoms, quality of life and cytokine profile in hemodialysis patients. Clin Nephrol, 73, 36-43

Murtagh, F.E., Addington-Hall, J. \& Higginson, I.J. (2007). The prevalence of symptoms in end-stage renal disease: a systematic review. Adv Chronic Kidney Dis, 14, 82-99

Noshad, H., Sadreddini, S., Nezami, N., Salekzamani, Y. \& Ardalan, M.R. (2009). Comparison of outcome and quality of life: haemodialysis versus peritoneal dialysis patients. Singapore Med J, 50, 185-192

O'donovan, A., Hughes, B.M., Slavich, G.M., Lynch, L., Cronin, M.T., O'farrelly, C., et al. (2010). Clinical anxiety, cortisol and interleukin-6: evidence for specificity in emotion-biology relationships. Brain Behav Immun, 24, 1074-1077

Ouzouni, S., Kouidi, E., Sioulis, A., Grekas, D. \& Deligiannis, A. (2009). Effects of intradialytic exercise training on health-related quality of life indices in haemodialysis patients. Clin Rehabil, 23, 53-63

Perlman, R.L., Finkelstein, F.O., Liu, L., Roys, E., Kiser, M., Eisele, G., et al. (2005). Quality of life in chronic kidney disease (CKD): a cross-sectional analysis in the Renal Research Institute-CKD study. Am J Kidney Dis, 45, 658-666

Pertosa, G., Grandaliano, G., Gesualdo, L. \& Schena, F.P. (2000). Clinical relevance of cytokine production in hemodialysis. Kidney Int Suppl, 76, S104-111

Raymond, C.B., Wazny, L.D. \& Honcharik, P.L. (2008). Pharmacotherapeutic options for the treatment of depression in patients with chronic kidney disease. Nephrol Nurs J, 35, 257-263; quiz 264

Riolo, S.A., Nguyen, T.A., Greden, J.F. \& King, C.A. (2005). Prevalence of depression by race/ethnicity: findings from the National Health and Nutrition Examination Survey III. Am J Public Health, 95, 998-1000

Sakkas, G.K., Sargeant, A.J., Mercer, T.H., Ball, D., Koufaki, P., Karatzaferi, C., et al. (2003). Changes in muscle morphology in dialysis patients after 6 months of aerobic exercise training. Nephrol Dial Transplant, 18, 1854-1861

Sareen, J., Cox, B.J., Afifi, T.O., De Graaf, R., Asmundson, G.J., Ten Have, M., et al. (2005). Anxiety disorders and risk for suicidal ideation and suicide attempts: a populationbased longitudinal study of adults. Arch Gen Psychiatry, 62, 1249-1257

Seabolt, J.L. \& De Leon, O.A. (2001). Response to nefazodone in a depressed patient with end-stage renal disease. Gen Hosp Psychiatry, 23, 45-46 
Sesso, R. \& Yoshihiro, M.M. (1997). Time of diagnosis of chronic renal failure and assessment of quality of life in haemodialysis patients. Nephrol Dial Transplant, 12, 2111-2116

Simic Ogrizovic, S., Jovanovic, D., Dopsaj, V., Radovic, M., Sumarac, Z., Bogavac, S.N., et al. (2009). Could depression be a new branch of MIA syndrome? Clin Nephrol, 71, 164172

Singh, A.K., Szczech, L., Tang, K.L., Barnhart, H., Sapp, S., Wolfson, M., et al. (2006). Correction of anemia with epoetin alfa in chronic kidney disease. N Engl J Med, 355, 2085-2098

Sklar, A.H., Riesenberg, L.A., Silber, A.K., Ahmed, W. \& Ali, A. (1996). Postdialysis fatigue. Am J Kidney Dis, 28, 732-736

Smogorzewski, M., Ni, Z. \& Massry, S.G. (1995). Function and metabolism of brain synaptosomes in chronic renal failure. Artif Organs, 19, 795-800

Son, Y.J., Choi, K.S., Park, Y.R., Bae, J.S. \& Lee, J.B. (2009). Depression, symptoms and the quality of life in patients on hemodialysis for end-stage renal disease. Am J Nephrol, $29,36-42$

Sonikian, M., Metaxaki, P., Papavasileiou, D., Boufidou, F., Nikolaou, C., Vlassopoulos, D., et al. (2010). Effects of interleukin-6 on depression risk in dialysis patients. Am J Nephrol, 31, 303-308

Stenvinkel, P., Heimburger, O., Paultre, F., Diczfalusy, U., Wang, T., Berglund, L., et al. (1999). Strong association between malnutrition, inflammation, and atherosclerosis in chronic renal failure. Kidney Int, 55, 1899-1911

Symister, P. \& Friend, R. (2003). The influence of social support and problematic support on optimism and depression in chronic illness: a prospective study evaluating selfesteem as a mediator. Health Psychol, 22, 123-129

Taskapan, H., Ates, F., Kaya, B., Emul, M., Kaya, M., Taskapan, C., et al. (2005). Psychiatric disorders and large interdialytic weight gain in patients on chronic haemodialysis. Nephrology (Carlton), 10, 15-20

Tsay, S.L. \& Healstead, M. (2002). Self-care self-efficacy, depression, and quality of life among patients receiving hemodialysis in Taiwan. Int J Nurs Stud, 39, 245-251

Victorri-Vigneau, C., Dailly, E., Veyrac, G. \& Jolliet, P. (2007). Evidence of zolpidem abuse and dependence: results of the French Centre for Evaluation and Information on Pharmacodependence (CEIP) network survey. Br J Clin Pharmacol, 64, 198-209

Watnick, S., Wang, P.L., Demadura, T. \& Ganzini, L. (2005). Validation of 2 depression screening tools in dialysis patients. Am J Kidney Dis, 46, 919-924

Weisbord, S.D., Fried, L.F., Mor, M.K., Resnick, A.L., Kimmel, P.L., Palevsky, P.M., et al. (2007a). Associations of race and ethnicity with anemia management among patients initiating renal replacement therapy. J Natl Med Assoc, 99, 1218-1226

Weisbord, S.D., Fried, L.F., Unruh, M.L., Kimmel, P.L., Switzer, G.E., Fine, M.J., et al. (2007b). Associations of race with depression and symptoms in patients on maintenance haemodialysis. Nephrol Dial Transplant, 22, 203-208

Weissman, M.M., Bland, R.C., Canino, G.J., Faravelli, C., Greenwald, S., Hwu, H.G., et al. (1996). Cross-national epidemiology of major depression and bipolar disorder. JAMA, 276, 293-299

Wichers, M. \& Maes, M. (2002). The psychoneuroimmuno-pathophysiology of cytokineinduced depression in humans. Int J Neuropsychopharmacol, 5, 375-388 
Winkelmayer, W.C., Mehta, J. \& Wang, P.S. (2007). Benzodiazepine use and mortality of incident dialysis patients in the United States. Kidney Int, 72, 1388-1393

Wolcott, D.L., Nissenson, A.R. \& Landsverk, J. (1988). Quality of life in chronic dialysis patients. Factors unrelated to dialysis modality. Gen Hosp Psychiatry, 10, 267-277

Wyne, A., Rai, R., Cuerden, M., Clark, W.F. \& Suri, R.S. (2011). Opioid and benzodiazepine use in end-stage renal disease: a systematic review. Clin J Am Soc Nephrol, 6, 326-333

Ye, W., Zhao, Y., Robinson, R.L. \& Swindle, R.W. (2011). Treatment patterns associated with Duloxetine and Venlafaxine use for Major Depressive Disorder. BMC Psychiatry, 11, 19 


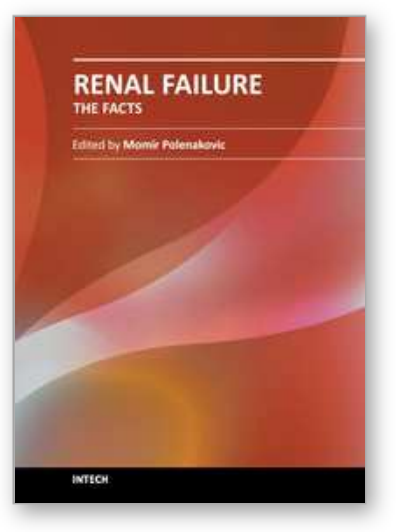

\author{
Renal Failure - The Facts \\ Edited by Dr. Momir Polenakovic
}

ISBN 978-953-51-0630-2

Hard cover, 270 pages

Publisher InTech

Published online 23, May, 2012

Published in print edition May, 2012

The book "Renal Failure - The Facts" consists of some facts about diagnosis, etiopathogenis and treatment of acute and chronic renal failure. Acute, as well as chronic renal failure is great medical problems and their treatment is a burden for the budget of each government. The purpose of the chapters is to present some important issues of diagnosis and causes of AKI, as well as caused by snakes and arthropods, after cardiac surgery, as well as some therapeutic achievements in AKI. Well presented are the psychological condition in patients on haemodialysis, as well as the treatment of diabetic uremics. The book is aimed at clinicians with a special interest in nephrology, but it should also prove to be a valuable resource for any generalists who encounter a nephrological problems in their day-to-day practice.

\title{
How to reference
}

In order to correctly reference this scholarly work, feel free to copy and paste the following:

Liang-Jen Wang and Chih-Ken Chen (2012). The Psychological Impact of Hemodialysis on Patients with Chronic Renal Failure, Renal Failure - The Facts, Dr. Momir Polenakovic (Ed.), ISBN: 978-953-51-0630-2, InTech, Available from: http://www.intechopen.com/books/renal-failure-the-facts/the-psychological-impact-ofhemodialysis-on-patients-with-chronic-renal-failure

\section{INTECH}

open science | open minds

\section{InTech Europe}

University Campus STeP Ri

Slavka Krautzeka 83/A

51000 Rijeka, Croatia

Phone: +385 (51) 770447

Fax: +385 (51) 686166

www.intechopen.com

\section{InTech China}

Unit 405, Office Block, Hotel Equatorial Shanghai

No.65, Yan An Road (West), Shanghai, 200040, China

中国上海市延安西路65号上海国际贵都大饭店办公楼405单元

Phone: +86-21-62489820

Fax: +86-21-62489821 
(C) 2012 The Author(s). Licensee IntechOpen. This is an open access article distributed under the terms of the Creative Commons Attribution 3.0 License, which permits unrestricted use, distribution, and reproduction in any medium, provided the original work is properly cited. 